Terbit online pada laman web jurnal : http://e-journal.sastra-unes.com/index.php/JILP

\begin{tabular}{|c|c|c|}
\hline \multirow[b]{2}{*}{$\begin{array}{l}\text { Fakultas Sastra } \\
\text { Universitas Ekasakti }\end{array}$} & \multicolumn{2}{|c|}{$\begin{array}{c}\text { (JURNAL ILMIAH LANGUE ANJ PAROLE) } \\
\text { VOLUME } 2 \text { NOMOR } 2\end{array}$} \\
\hline & $\begin{array}{c}\text { ISSN : 2581-0804 } \\
\text { (Media Cetak) }\end{array}$ & $\begin{array}{c}\text { E-ISSN : 2581-1819 } \\
\text { (Media Online) }\end{array}$ \\
\hline
\end{tabular}

\title{
AN ANALYSIS OF RACIAL DISCRIMINATIONS AS SEEN IN KATHRYN STOKETT'S NOVEL THE HELP
}

\author{
Marleni Zairanis Nazara, Fetri Reni \\ Fakultas Sastra Universitas Ekasakti \\ *Corresponding Author: Fetri Reni \\ Fakultas Sastra Universitas Ekasakti \\ fetrirenisastra@gmail.com
}

\begin{abstract}
The problem in this analysis is the existence of black racial discrimination by white people who consider themselves more powerful than the black race. This is illustrated in the novel The Help through the treatment of white employers against their helpers, the black race. In this analysis, the author wants to analyze discriminatory actions, causes and effects of racial discrimination in the novel The HelpIn this analysis, descriptive research is taken as a method of data collection. As for the method of data analysis, the authors conducted qualitative methods with understanding the novel. Data collection techniques use qualitative techniques by taking notes in collecting primary data. In data analysis techniques, the author uses structuralism method techniques by interpreting data.The results of this research are: 1) there are elements and acts of discrimination and segregation from white employers to black maids and also various racist actions towards other blacks described in the novel. 2) the cause of racial discriminations in this novel stems from Hilly's idea of making separate toilets with black maids 3) The effect of this racial discriminations is the publication of the novel The Help in Mississippi, the changing viewpoint of their employers and helpers and vice versa.
\end{abstract}

Keywords: Racism, Mimetic, Discrimination

(C) 2019Jurnal JILP

\section{INTRODUCTION}

This research which entitled "An analysis of racial discrimination as seen in Kathryn Stockett's novel The Help" focus on racial discriminations, causes and effect of the racism after colonization period in Jackson, Mississippi based on The Help novel by Kathryn Stockett. The novel is able to tell the racial discrimination from the smallest part of society.

The reason for choosing this novel as a research material is because the writer wants to analyze about racial discrimination from a literature works, and also the writer wants to analyze the causes and the effects of that racism in The Help novel.

Historically racism developed when different races met in the context of colonization. Paul Spoonley in his book Ethnicity and Racism (1990) attempted to trace the paths of racism, he concluded that race is a colonial concept that developed when the spirit to expand into Europe. From then on, the concept of race in the realm of sociological interaction of the world was introduced. As part of a colonial ideology, racism legitimized the exploitation of European white colonial society against other races. Paul 
Spoonley traces such cases to the Maori descendants among the

white race community in New Zealand. The same goes for the black race community in America.

The belief in the superiority of the race continues to be reproduced and negotiated hegemonically by the ideology and institutions of neocolonialism so that the problem of racism remains like a tangled thread that is difficult to resolve. Sniderman (1991: 423) explains that racism has not disappeared, but it replaced by a new form of racism that is hegemonic, implicit, veiled, and as if not racist. Racial prejudice and discrimination are no longer expressed freely and explicitly. Because if prejudice and discrimination are stated openly it will be contrary to the legal and legal issues that prohibit it.

After many decades have passed until the present time, there are still many people who do not know what racial discrimination experienced by black people at that time was; ranging from mild to dangerous and eliminating many lives. through this research, the author also wants to express what the effects of the discrimination are, and what is the real form of separation between black and white people in that era both in this novel and in real life.

\section{A. Literature Review}

\section{Mimetic Theory}

Aristotle in Abrams (1979: 8) describes the term "mimetic" that art as an imitation of aspects of the world. The author of the novel The Help applies a reflection of the life experiences of black people in fiction novels. This theory explained that the story of this novel is considered a replica of the lives of black people in America. George Luckas in Selden (2005: 87), a novel reflect reality, not by contributing to the presence of its surface but also by providing a clearer picture of real life, more complete, and more dynamic. This theory explains that, The Help novel can see as a picture of reality adapted into a fictional novel that takes pictures the social life of black people. Furthermore, Taine in Wellek and Warren (1959: 5) explains that literary works are the result of three factors, namely: race, moment and social environment. This explanation reveals how these three points affect the character of American black figures according to their race are of African descent who have been impacted by the application of Jim Crow Laws in the 60s.

\section{Racism}

Racism, on the other hand, is viewed as the coordinated interaction of particular types of stereotypes, prejudices, and discrimination (Jones, 1997). Jones (1997), further suggests that racism has three fundamental components. First, racism is rooted in beliefs about group differences (stereotypes) that are assumed to reflect fundamental biological differences. Second, racism involves well-differentiated negative evaluations and feelings about another group (prejudice) in comparison to one's own. Whether or not the other group is described explicitly as inferior, one's own group is believed to be superior. Third, racism reflects the disparate treatment of groups (discrimination) by individuals and institutions in ways that are justified by and tend to perpetuate negative beliefs, attitudes, and outcomes.

\section{B. Discriminations}

Discrimination is the act of someone being prejudiced towards another. This term is used to highlight the difference in treatment between members of different groups when one group is intentionally singled out and treated worse, or not given the same opportunities. Attitudes toward minorities have been marked by discrimination historically in the United States. Many forms of discrimination have come to be recognized in U.S. society, on the basis of national origin, race, gender, and sexuality in particular (Harcourt, 19:2008). 


\section{RESEARCH METHODS}

The writer divides the method of research into the method of collecting data by use descriptive methods from Gall \& Borg (2007), method of analyzing data procedure by taking the primary data from the novel to find some intrisic elements as Marie (2016) suggest. Technique of data collecting uses qualitative research by

\section{RESULTS AND DISCUSSION}

The racist problem that actually existed long before the first part of the novel is raising when Hilly put the idea of the Home Help Sanitation Initiative, which she announced at a bridge meeting of white women at Elizabeth's house. It would require all Mississippi families to build outdoor bathrooms for their black employees. Hilly seems to truly believe that black people carry diseases that can harm white people. Apparently these diseases can only be passed through toilet seats, because black hands touch almost every piece of food Hilly eats, every fork her lips touch, and the pillowcases she lays her head on.

"All these houses they're building without maid's quarters? It's just plain dangerous. Everybody knows they carry different kinds of diseases than we do. I double" (8)

Hilly is the novel's dastardly villain. She's married to William Holbrook and has two children, Heather and William, Jr. According to Aibileen, one of her few redeeming qualities is the love and kindness she shows her two children. Hilly is one of the few characters analyzed in depth by all three of The Help's narrators - Aibileen, Minny, and Skeeter - and her conflicts with these characters unite them.

On the surface, Hilly's no mustache-twirling villain. In fact, she appears to be totally respectable. She's president of the Jackson Junior League and active in all sorts of charity, including collecting canned goods for The Poor Starving Children of Africa. To give you an idea of Hilly's motives, check out her response when a woman asks why they don't send money instead of cans:
Creswell (1998:41, and technique of the data analyzing procedure use structuralism method by Pradopo in Metodologi Penelitian Sastra (2001: 54). This method provides the steps of writer in collecting and analyzing the data.

"You cannot give these tribal people money [...]. There is no Jitney 14 Grocery in the Ogaden Desert. And how would we even know if they're even feeding their kids with it? They're likely to go to the local voodoo tent and get a satanic tattoo with our money." (99)

The problem heated up when hilly friends, Skeeter who had just returned from college abroad felt a shock culture because according to her, Hilly's idea was too harsh and had no humanist side. Even more so when hilly said that, Aibileen was there and heard everything. She's been best friends with Hilly Holbrook and Elizabeth Leefolt (villainous characters) since grade school. But as the story progresses, Skeeter becomes more and more distanced from this safe social status and goes, as they say, rogue.

\section{The Causes of Racism}

In the novel white and black people were supposed to have separate bathrooms since according to the white people, black people were dirty. This in itself tells about one of the many contradictions that occur in the novel. On the one hand, the colored people are not allowed to use the white's bathrooms because they have diseases and dirty. On the other hand, the white people want them to clean their houses, cook their food and take care of their children. Furthermore, Aibileen compares herself with a cockroach:

That night after supper, me and that cockroach stare at each other down across the kitchen floor. He big, inch, inch and a half. He black. Blacker than me. (189)

This could indicate that there are not only the white people who have a patronizing attitude 
towards black people, but Aibileen looks down on herself too. To compare herself with an insect, a pest, is to acknowledge herself as dirty and potentially harmful.

Focused as it is on female characters, white and black, The Help portrays how the home, a traditionally feminine space, was just as much a battleground for social change as were the courtrooms and rallies of the 1960s Civil Rights Movement. While Aibileen describes how white men beat or kill black men who "stepped out of line," the novel also shows how white women used their social influence to ruin the lives of the black maids in more indirect but similarly devastating ways. A white woman could have her maid fired, her maid's husband fired, their house repossessed, or even have her maid sent to jail for as small an infraction as a parking ticket.

\section{The Effect of Racial Disciminations}

At its core, The Help is an exploration of the ways in which racism pervaded every aspect of

\section{CONCLUSION}

"Help" is normally signifies the giving of free services or resources to those in need, but the novel's title refers directly to the underpaid black domestic workers who, paradoxically, are the ones "helping" their wealthier and more powerful employers, people who have no real need of help. By referring to these women as "the help," the white housewives uphold the illusion that the maids are like volunteers who want, or should be grateful for the opportunity, to work for less than minimum wage, and for families that treat them as subhuman. The white women refuse to even consider that they could be the ones "helping" the maids by promoting civil rights in white communities.

This irrational and absurd system in which poor black people "help" the rich whites gives way to widespread hypocrisy in white society. social life in 1960s Jackson, Mississippi, from Jim Crow laws that sanctioned discrimination and segregation as official policy to casual conversations between middle-class white women. In particular, the novel focuses on how white housewives justified the exploitation and emotional abuse of their black maids by convincing themselves that black people are fundamentally different from, and inferior to, white people. Miss Hilly openly expresses the belief that African-Americans are figuratively and literally "unclean," prone to moral depravity and infectious diseases not carried by whites. On a larger scale, almost every white woman in the novel performs the social practices that reinforce the institutional separation of whites and blacks under Jim Crow-era law. The white women don't let their maids touch them, sit at their table, or share their food. These everyday practices dehumanize the maids and make it easier for the housewives to exploit their maids' labor.

Miss Hilly believes that her bathroom bill and Jim Crow segregation laws actually "help" black people. She even takes the moral high ground by raising funds to "help" needy children in Africa, but this is actually a false generosity meant to raise her class status as a charitable woman. Hilly is not capable of understanding that this desire is rooted in a racist paternalism that infantilizes black people as completely helpless, adding further irony to the fact that the black domestic workers are actually the ones "helping" their white employers. If Hilly truly cared about generosity and not merely the appearance of generosity, she would provide fair wages to the woman working in very own her kitchen, not as an act of charity but as a way of amending a social injustice. 


\section{Bibliography}

[1]Anderson, Joan. 2014. Lesson from a postcolonial-feminist perspective : suffering and a path to healing journal. Canada: Nursing Inquiry.

[2]Bogdan, Robert. 2007. Qualitative Research for Education: An Introduction to Theory and Methods Jounal $8^{\text {th }}$ edition. USA: Pearson.

[3]Borg, R Walter \& Joyce P. Gall \& M.D Gall. 2007. Educational Research: An Introduction, $8^{\text {th }}$ Edition. USA: Cloth.

Clair Matthew, Jeffrey Dennis. 2001. Racism, Sociology Journal.

Harvard:Elvesier Ltd

[4]Cozzens, Lisa. "Mississippi \& Freedom Summer". African American History. February 23, 2019. http://www.watson.org/ lisa/blackhistory/ci vilrights-55-65/missippi.html. 8:48 PM

[5]Doyle, Louise and Anne Marie Brady and Gobnait Byrne. 2016. An Overview of mixed Method Research. Canada. SAGE Publisher.

[6]Ellis, K. and Smith, S. State of Siege, Mississippi Whites and the Civil Rights Movement: Defiance and Compliance. American Public Media. January 13, 2019. http://americanradioworks.publicradio.org/f eatures/mississippi/e1.html. 9.24 PM

[7]Harcourt, M. 2008. Discrimination in hiring against immigrants and ethnic minorities: the effect of unionization". The International Journal of Human Resource Management.

[8]Hood, Susan. 2010. Apraising Research: Evaluation in academic writing. Palgrave Macmillan. Britain

[9]Harcourt, M. 2008. Discrimination in hiring against immigrants and ethnic minorities: the effect of unionization". The International Journal of Human Resource Management

[10]John M, Cresswell. 1998. Research Design: Qualitative, Quantitative, and Mixed Methods Approaches. Canada. SAGE Publisher.

[11]Joseph, Tiffany D. Black Women in the Civil [26]Szulkowska, Agata. 2017. The problem of Rights Movement: 1960-1970. BrownTougaloo Exchange, Freedom Now! $23 \quad$ February 2019. http://cds.library.brown.edu/projects/Freedo
mNow/tiffany joseph thesis.html. 9:05 PM.

[12]Marshall, JoAnn. The Roles of Southern Women, Black and White, in Society. University of Alabama, Sigma Tau Delta Conventions. 02 March 2019. http://www.bama.ua.edu/ sigmatau/texts/so uthern.html. 7:50PM.

[13]Melbom, Josephine. 2014. From a novel to the exploration of social issues journal. New York: Gymnase Auguste Piccard.

[14]Mirsha, Raj. 2013. Postcolonial feminism: Looking into within-beyond-to journal. India: Varanasi.

[15]Nassaji, Hossein. 2015. Qualitative and descriptive research: Data type versus data analysis journal. Canada: SAGE Publisher.

[16]Liliweri, Alo. 2005. Prasangka dan konflik. Jogjakarta: Multikultur.

[17]Loomba, Ania. 2003. Postcolonial feminism Journal. Boston: Rouledge.

[18]Oomen. 1997. Citizenship \& National Identity: From Colinialism to Globalism. Canada: SAGE Publisher.

[19]Pattitihahuwan Febrina I. 2008. The analysis of racism in The Help novel. Manado: Fakultas Ilmu Budaya Sam Ratulangi.

[20]Pradopo, Rachmat Djoko, et.al. 2001. Metodologi Penelitian Sastra. Yogyakarta: PT. Hanindita Graha Widia.

[21]Ramussen M, Brian and Ann Marie. 2016. Social Works in Line of Duty: Racism in Health Care. London: NASW Publisher.

[22]Sniderman, Paul and Thomas Piazza. 1991. The Scar of race. London: Cambridge University.

[23]Spoonley, Paul. 1990. Ethnicity and Racism. Australia: OUP Australia.

[24]Suastrifa, Maya Danastri. 2011. The representation of racial discrimination in The Help novel by Kathryn Stockett journal. Jakarta: UIN Syari Hidayatulah.

[25]Stockett, Kathryn. 2009. The Help. New York: Penguin. racism in Kathryn Stockett's novel The Help journal. University of Bilystok: Crossroads.

Jurnal JILP (Jurnal Ilmiah Langue and Parole) Vol. 2 No. 2 (2019) ISSN : 2581-0804

This work is licensed under a Creative Commons Attribution-NonCommercial 4.0 International License. 
[27]Vieytes, Vilarino. 2010. 'white guilt': a new [29]Wellek, René and Warren, Austin. 2016. excuse for another colonialst move. 'first Theory of Literature and Criticism New Edition. world feminism' and 'third world women' USA: Harcourt Yale University.

in The Help journal. London: University of Leeds.

[28]Watson, Bruce. 2011. Freedom Summer. New York: Penguin. 